\title{
49
}

\section{SHAREHOLDER RELATIONS AND COMMUNICATION}

\author{
Claire Fargeot
}

"Managing expectations" has historically been the mantra for the careful balancing of board-level shareholder relations and communication. Investors have always demanded "openness and transparency" in communications from their targeted or invested companies. Boards of directors, however, have generally tended to err on the side of caution, particularly when things have not developed as planned. This tension has led to growing pressure for greater board transparency and more open communication from activist investment funds, hedge funds, governance professionals, NGOs, and other stakeholders.

Shareholder activism has been on the rise since the global financial crisis for both large and small enterprises, and there appears little sign of that abating. Shareholders are looking for assurances that the enterprise has a solid strategic direction and a viable business model. Within the listed company space, shareholders are looking for access to management and reporting that includes trackable metrics that measure performance and long-term sustainable growth with a sensible approach to executive compensation that is directly linked to strategy delivery, operational and financial results, and meaningful non-financial measures. 
Today's regulatory environment is changing for the investment community as well as for companies, and institutional investors are required to intensify oversight of their portfolio companies, disclosing their governance policies, voting practices, and engagement activities. The financial crisis made plain the failures that resulted from too heavy a reliance on purely quantitative analysis to evaluate an organisation's performance, and investors are taking intangible assets and non-financial performance metrics into account in their company evaluations. This enlarged reporting and analytical framework has important implications for companies, and specifically for directors, as responsibility for environmental, social, and governance (ESG) issues and sustainability falls to the board. It is the directors, rather than management, that are answerable for ESG and sustainability issues by shareholders.

\section{Managing expectations}

In many international markets the board's role is broadly defined, requiring directors to balance a multitude of competing demands (managing conflicts of interest, including those resulting from significant shareholdings, dealing with workforce representation, and ensuring that the influence of third parties does not compromise or override independent judgement), in addition to their oversight duties. In these markets the need for transparency is even more compelling than in the more highly regulated markets, such as the UK, the EU, and the USA, where comprehensive legal, disclosure, and accounting standards are well established. The provisions contained in the UK Code ${ }^{1}$ act as a reminder of what is expected of UK premium-listed company directors in terms of shareholder relations and engagement:

- In addition to formal general meetings, the chair should seek regular engagement with major shareholders in order to understand their views on governance and performance against the strategy. Committee chairs should seek engagement with shareholders on significant matters related to their areas of responsibility. The chair should ensure that the board as a whole has a clear understanding of the views of shareholders. 
- When 20 per cent or more of votes have been cast against the board recommendation for a resolution, the company should explain, when announcing voting results, what actions it intends to take to consult shareholders in order to understand the reasons behind the result. An update on the views received from shareholders and actions taken should be published no later than six months after the shareholder meeting. The board should then provide a final summary in the annual report and, if applicable, in the explanatory notes to resolutions at the next shareholder meeting, on what impact the feedback has had on the decisions the board has taken and any actions or resolutions now proposed.

Outside the listed company space, certain boardrooms are particularly opaque, with complex shareholding structures such as state-owned enterprises or large private organisations dominated by controlling groups or founding families. Directors that are large shareholders too, such as in many private equity-backed organisations, have to respond to their outside investors' interests as well as look after their own. All in all, managing expectations is not as easy as it sounds, and the experience of increasing levels of transparency has not always been a comfortable one for many directors.

\section{Dealing with activists}

Listed-company approaches for dealing with activists have tended to rely on direct targeted engagement methods such as formal letters, orchestrated meetings, and selective outreach campaigns. When the situation becomes more critical, approaches rely much more heavily on external expertise, such as crisis PR agency support or proxy solicitation. However, such an approach is reactive and does not tend to support a long-term basis for positive relations and a prevention of shareholder activism. The prime concern for any board should of course be to act in such a way that it leaves no space for activism - being proactive rather than reactive. As soon as shareholders express concern, it should be dealt with efficiently with a view to removing that particular concern completely. Past experience tends to dictate that if a board does not respond, then shareholders will become more vocal and active. Boards looking to reduce shareholder dissent should 
follow strategies that are likely to provide an effective prevention approach, such as providing access to key senior team members and pertinent information when requested and so on.

\section{Becoming a transparent board}

Board transparency is the recognised accountability mechanism for organisations subject to principles-based, comply-or-explain governance systems. However, this system is not perfect as explanations are only required where companies are non-compliant. As a result, this exceptionsbased reporting approach tends to encourage related communication that has gaps, being fragmented and oftentimes, unrelated to other disclosures. Both companies and shareholders would benefit from an annual board narrative and a structured programme for directors to communicate and engage with shareholders.

The board of directors is essentially responsible for its statutory duties, (including ESG and sustainability issues), whilst management is responsible for everything else, including the day-to-day business operations, financial performance, and the execution of strategy. Being clear about this differentiation provides the basis for what can be discussed with shareholders, and meetings planned for the board to meet directly with shareholders should be done so in reflection of this and with care.

Generally speaking, board effectiveness communication requires improvement, with only $51 \%$ of companies providing good or detailed explanations in this area and only $46 \%$ providing sufficient detail on outcomes. ${ }^{2}$ Shareholders view regular board evaluation as an important accountability mechanism for corporate boards. Ideally, the board should commission independent board evaluation experts to conduct an effectiveness review in order to gauge shareholder satisfaction with the board, executive leadership, and overall strategic direction. This review should examine the governance practices, interviewing directors and senior management, observing the board in action, carrying out a shareholder perception survey, and studying the board packs. The findings should be communicated in a non-attributable way to the entire board and a work plan for improvement should be communicated to stakeholders via the annual report. 


\section{Questions to ask}

- Does the board recognise the importance of listening to, and understanding the views of its shareholders so that this information can be used to inform decision-making?

- Does the board understand how and via what means the shareholders want to be communicated with?

- Is the board approach and narrative on shareholder relations and communications clear?

- Is there an effective mechanism of tracking shareholder relations and communication?

- Has the board clearly defined and communicated its own remit?

- Does the board tell a compelling story about its own board effectiveness?

- Does board effectiveness have a commitment to the business goals, ESG, and sustainability?

- Are the shareholders and stakeholders convinced of this?

- What are the views of the current shareholders and stakeholders on the board's effectiveness?

- Does the board regularly conduct an evaluation of its own governance practices and standing? If not, why not?

- Does the board have access to the relevant information for appropriate shareholder relations?

- What are the aspects that shareholders and stakeholders take issue with (or have taken issue with, in the past)?

- Does the board engage with activist investors (now and has it done so in the past)?

- Does the board have clarity on the objective of its engagement campaign?

- Is the board informed as to what topics are on the agenda?

- Is the board clear on who should speak for the board?

- Is it clear with whom the board should engage?

- Does the board understand when and how engagement should occur?

- Is it clear who from management should participate in the engagement process?

- Is it clear what is missing from the current communication to shareholders and stakeholders? 